\title{
"Gathering the Dispersed of Israel": The Evolution of a Kabbalistic Prayer Addendum for Tiqqun Qeri
}

\author{
Patrick Benjamin Koch
}

University of Hamburg; patrick.benjamin.koch@uni-hamburg.de

\section{Abstract}

This article traces the evolution of a kabbalistic prayer supplication that was designed to purify male Jews from pollution caused by improper seminal emission. In doing so, it focuses on the metaphysical rationale behind it, its function, and its metamorphosis from a highly technical practice into a mainstream devotional practice. It addresses how notions of sexual pollution (qeri) were contextualized in Lurianic Kabbalah and how they were later embedded in kabbalistic manuals and prayer books. Furthermore, the article examines Jewish-Christian and innerJewish debates that emerged in connection with the effects of spilling semen in vain. Special attention is paid to possible social factors that may have impacted the increased anxiety about male bodily fluids and "misguided" desires. In addition to the available research on the theological and general historical background of the prohibition of wasting seed, the following analysis offers a microhistory of this short yet highly influential text.
\end{abstract}

\section{Keywords}

Jewish mysticism, Kabbalah, prayer, Early Modern Judaism, male sexual pollution, waste of seed, Jewish-Christian polemics

\footnotetext{
(C) The Author(s), 2021. Published by Cambridge University Press on behalf of the President and Fellows of Harvard College. This is an Open Access article, distributed under the terms of the Creative Commons Attribution-NonCommercial-NoDerivatives licence (http://creativecommons.org/licenses/by-nc-nd/4.0/), which permits non-commercial re-use, distribution, and reproduction in any medium, provided the original work is unaltered and is properly cited. The written permission of Cambridge University Press must be obtained for commercial re-use or in order to create a derivative work.
} 


\section{Introduction}

In the aftermath of the spiritual-mystical heyday of sixteenth-century Safed, kabbalistic materials soon began to circulate in manuscript outside the land of Israel. ${ }^{1}$ At the same time, crucial elements of Safed's spiritual and pietistic ideals were disseminated in print via hagiography, pietistic literature (musar), kabbalistic anthologies, and prayer books.

During the seventeenth and early eighteenth centuries, prayer addenda associated with the Lurianic branch of Kabbalah were incorporated into a large number of siddurim and mahzorim, long before the nascent Hasidic movement adopted the prayer rites of Isaac ben Solomon Luria Ashkenazi (1534-1572). In particular, strategies of purification took pride of place in the complementary sections of the conventional wording of prayers and benedictions.

One of the most prominent supplications is a short passage associated with the tenth blessing of the eighteen-benediction prayer, or Amidah, which was designed to purify male Jews from pollution caused by improper seminal emission. Between the recitation of "Sound the great Shofar for our freedom and raise a banner to gather our exiles and unite us together from the four corners of the earth" and the concluding line of the blessing - "Blessed are You, Lord, who gathers the dispersed of His people Israel"- men were instructed to insert the following short addendum:

May it be the will before you, Lord, our God and God of my fathers, that each and every drop [of semen] that came out of me, whether under coercion or willingly, which did not [serve to fulfil a positive] commandment, for the sake of Your great name that stems from the verse "The riches he swallows he vomits; God empties it out of his stomach" (Job 20:15), that You shall return it to the holy place and do what is considered good in your eyes. ${ }^{2}$

This rather obscure text rapidly gained popularity in the course of the seventeenth century and by the end of the eighteenth century, it was so widespread that it could easily be found in a large number of non-kabbalistic prayer books. Its remarkable rise, as well as its later decline in the nineteenth century, is not only a prime example to illustrate the dissemination of kabbalistic thought but also provides fascinating insights into the sociology of knowledge of early modern and modern Jewry.

This article traces the history of this extraordinary prayer. It focuses on the metaphysical rationale behind it, its function, and its metamorphosis from a highly technical practice into a mainstream devotional practice. It addresses how notions of sexual pollution (qeri) were contextualized in the writings of Hayyim Vital and other disciples of Luria and how they were embedded in kabbalistic manuals and prayer books. Furthermore, the article examines Jewish-Christian and inner-Jewish debates that emerged in connection with the effects of spilling semen in vain. In

${ }^{1}$ This research was made possible by the generous support of the German Research Foundation (DFG), in the framework of the Emmy Noether project "Jewish Moralistic Writings of the Early Modern Period: 1600-1800" (Project No. 320105005).

${ }^{2}$ MS New York JTS 1585, 264a. 
doing so, special attention is paid to possible social factors that may have impacted the increased anxiety about male bodily fluids and "misguided" desires. In addition to the available research on the theological and general historical background of the prohibition of wasting seed, the following analysis offers a microhistory of this short yet highly influential text.

\section{The Status of Qeri: Some General Remarks}

In several illuminating studies, scholars such as Meir Benayahu, David Biale, Gershon Hundert, Shaul Magid, Elliot Wolfson, and, most comprehensively, Shilo Pachter have shown that the prohibition of wasting seed took pride of place in certain branches of medieval and early modern Kabbalah. ${ }^{3}$ In the main body of the Zohar, the status of qeri is repeatedly depicted as one of the gravest transgressions - if not the gravest — prohibited by the Torah. With reference to Gen 38:9 and related talmudic discussions, it is stated, for example, that "there is nothing in the world for which one cannot repent, except for [wasting his seed on the ground]." Elsewhere, the Zohar goes even further, stating that the person who violates this prohibition is worse than a murderer, "because they kill other men. However, the [one who wastes his seed] kills his own actual children, shedding blood in abundance." 5 The majority of kabbalists living in Safed during the second half of the sixteenth century adopted this notion. ${ }^{6}$ Hayyim Vital, for example, in his moralistic and mystical treatise $\breve{S} a$ 'arey Qedušah, twice refers to wasting sperm as the "greatest transgression of all," because the sinner spills the blood of his own offspring. ${ }^{7}$

These short remarks could be read as part of a vigorous debate about defining the beginning of personhood, which is doubtless one of the key challenges of contemporary bioethics. ${ }^{8}$ However, in the present context, the strong opinions on

\footnotetext{
${ }^{3}$ Meir Benayahu, Studies in Memory of the Rishon Le-Zion R. Yitzhak Nissim: Ma'amadot u-Moshavot (Jerusalem: Yad ha-Rav Nissim Publishers, 1995) 81-104 (Hebrew); David Biale, Eros and the Jews: From Biblical Israel to Contemporary America (New York: Basic Books, 1992) 109-10; Gershon Hundert, Jews in Poland-Lithuania in the Eighteenth Century: A Genealogy of Modernity (Berkeley: University of California Press, 2004) 131-37; Shaul Magid, From Metaphysics to Midrash: Myth, History, and the Interpretation of Scripture in Lurianic Kabbala (Bloomington: Indiana University Press, 2008); Elliot R. Wolfson, Language, Eros, Being: Kabbalistic Hermeneutics and Poetic Imagination (New York: Fordham University Press, 2005) 511 n. 264, 566-67 n. 116; Shilo Pachter, "Shmirat Habrit: The History of the Prohibition of Wasting Seed" (PhD diss., The Hebrew University of Jerusalem, 2006) (Hebrew).

${ }^{4}$ Sefer ha-Zohar (ed. Reuven Margaliot; 3 vols.; Jerusalem: Mossad ha-Rav Kook, 1960) 1:219b-21b (translation in Daniel Matt, The Zohar: Pritzker Edition [12 vols., Stanford, CA: Stanford University Press, 2006] 3:328 and 3:327 n. 143). Cf. also Zohar 1:88a and b. Nid. 13a; Maimonides, Mishneh Torah, Hilkhot 'Issurei Bi'ah, 21:18; Joseph Karo, Šulhan 'Aruk, 'Eben ha'Ezer, 23:1 (Qapust, 1813) 36a.

${ }^{5}$ Zohar 1:219b (translation in Isaiah Tishby, The Wisdom of the Zohar: An Anthology of Texts [trans. David Goldstein; 3 vols.; Oxford: Littman Library of Jewish Civilization, 1989] 3:1366).

${ }^{6}$ See, e.g., Benayahu, Studies, 81-88.

${ }^{7}$ Ḥayyim Vital, Ša 'arey Qedušah (Jerusalem: Eshkol, 1985) 57, 67.

${ }^{8}$ They could thus be read as referring to the status of the unborn prior to the fertilization of the
} 
wasting semen express a different, albeit no less radical, idea. As Shilo Pachter has shown, the Lurianic notion of wasting seed is first and foremost understood as a creative rather than destructive act. ${ }^{9}$ Vital himself articulates this view in his Ša 'ar ha-Tefillah, where he writes:

\begin{abstract}
Know that none of the transgressions of the Torah - even the gravest onesproduce actual destructive forces (meziqin), to the degree accomplished by the waste of sperm. . . . Even if one is drawn to all of the [sexual] relationships prohibited by the Torah, they produce corporeal bastards in this world. . . . But know that the one wasting his seed causes damage [in the realm of] thought (mah̆šabah), because he does not use any vessel or genitalia [of the opposite sex], ... and because his actions are male without female, he causes on high that the very drop of this particular soul continues from the upper male without emanating into Malkut, but exits towards the husk (qelippah), which is called "the husk of noga" (qelippat nogah). ${ }^{10} \ldots$ There is the adulterous woman of the Other Side . . . and this very soul is drawn to her, and hence one of the destructive forces that stems from the same adulterous woman joins it, and it is made an aspect of body to soul. It follows that the one who wastes his seed causes the very drops of the souls . . . to intermingle with the Other Side, and there they will be clothed with bodies that are made from the Side of the Snake, the adulterous woman. And it follows that he turned . . . holiness into impurity, and good into evil. ${ }^{11}$
\end{abstract}

Vital is here referring to four interrelated points that are worth investigating in more detail. First, his theory of the creation of souls is founded on the medieval kabbalistic concept that semen stems from the brain of the male. It is instilled with a soul that originates in the upper worlds by means of the male's intentions during intercourse. This process had already been outlined in the anonymous treatise 'Iggeret ha-Qodesh, traditionally attributed to the medieval kabbalist Nahmanides (1194-1270). The fact that 'Iggeret ha-Qodesh is included in full in Elijah de Vidas's (1518-1587) kabbalistic moralistic anthology Rešit Hokmah clearly shows that Vital's contemporaries in Safed held this work in the highest esteem. ${ }^{12}$

egg, or the mere prevention of the creation of a potential living being as an act of murder. If this were the case, the extreme nature of such an approach becomes apparent when compared to the regulations on stem cell research in the State of Israel today, which, although disputed, is supported by the halakhic definition of the beginning of life after forty days of gestation (see, e.g., John D. Loike, "Halachic Challenges Emerging From Stem Cell Research," November 27, 2018, http://jcpa. org/article/halachic-challenges-emerging-from-stem-cell-research/).

9 Pachter, "Shmirat Habrit," 195.

${ }^{10}$ For a study of the concept of the qelippah, see Isaiah Tishby, The Doctrine of Evil and the “Qelippah” (Jerusalem: Schocken, 1942) 137 (Hebrew).

${ }^{11}$ Vital, Ša 'ar ha-Tefillah, 207, and idem, Ša'ar ha-Kavvanot, 1:363.

${ }^{12}$ For 'Iggeret ha-Qodeš, see Kitḅei Rabeynu Moshe ben Naḥman (2 vols.; Jerusalem: Mossad Ha-Rav Kook, 2002) 2:315-37; Elijah de Vidas, Rešit Hoknmah (ed. Hayyim Yosef Waldmann; 3 vols., Jerusalem, 1984) 2:465-98. See also Wolfson, Language, Eros, Being, 314-16; idem, Venturing Beyond: Law and Morality in Kabbalistic Mysticism (Oxford: Oxford University Press, 2006) 87. 
Second, in the theosophical-theurgical branch of Kabbalah, the human being is conventionally perceived as a microcosm of the divine structure. As a result of this isomorphism, certain processes in the upper world can be initiated by actions performed in the mundane realm. In our case, the creation of souls on high is caused by the activation of semen below. Third, the coming into being of souls and semen basically follows the pattern of emanation. Emanation, which denotes creation as a process of materialization, begins on a quintessentially spiritual level that gains corporeality the further it advances. The waste of semen, according to Vital, therefore causes damage in the realm of thought: the place in which the essence of (Jewish) souls originates. Fourth, and perhaps most importantly, improper seminal emission of any kind constitutes a male autoerotic act. ${ }^{13}$ This means that both the seed below and the soul generated above lack their feminine counterparts. In Lurianic doctrine, those souls produced without "female waters" are considered superior to conventional souls as they resemble the first act of creation. ${ }^{14}$ However, as a result of their purely masculine nature, they "are taken by demonic female(s) ... and must be recovered through good deeds (misvot)."15 In this light, it becomes clear why Vital and others regard wasting semen as different from other transgressions: the latter have a damaging effect in this world, whereas the former have a creative effect in the realm of evil. ${ }^{16}$

\section{Rectifying Wasted Seed: Tiqqun Qeri}

Even though some Safedian kabbalists seemed to have adopted the rigorous idea of the impossibility of repenting for the transgression of wasting seed, they nevertheless devoted a significant part of their writings to outlining mental and bodily exercises that rectified sexual pollution. While elaborating on the presleep, or mapil, blessing recited during the bedtime Shema, Hayyim Vital, for example, distinguishes between different types and qualities of restorative practices (tiqqunim) effective in mitigating the effects of spilled semen as follows:

One must know that the main principle of this particular mental concentration (kavvanah) is to remedy and atone for one of the gravest transgressions, which is impeding the soul's ascent to her master at nighttime, ... And even

${ }^{13}$ On the types of improper seminal emission, see Hayyim Vital, Ša 'ar Ruah ha-Qodeš (Jerusalem: Ahavat Shalom, 2017) 145-48, and Lawrence Fine, Physician of the Soul, Healer of the Cosmos: Isaac Luria and his Kabbalistic Fellowship (Stanford, CA: Stanford University Press, 2003) 177.

${ }_{14}$ Pachter, "Shmirat Habrit," 187-92; Ronit Meroz, "Redemption in the Lurianic Teaching" (PhD diss., The Hebrew University of Jerusalem, 1988) 97-98 n. 4, 93, § 5.4 (Hebrew); Elliot R. Wolfson, Circle in the Square: Studies in the Use of Gender in Kabbalistic Symbolism (Albany: State University of New York Press, 1995) 69-74 and 188-89 nn. 169-70. Cf. also with Shaul Magid, "Conjugal Union, Mourning and Talmud Torah in R. Isaac Luria's Tiqqun Hazot," Daat 36 (1996) xvii-xlv, at xxix-xxx.

${ }^{15}$ Magid, From Metaphysics to Midrash, 61.

${ }^{16}$ For later adoptions of this notion, see, e.g., Șevi Hirsch Kaidanover, Qav ha-Yašar (Frankfurt Main, 1705) 30b; and cf. Joseph ben Solomon of Calahora, Sefer Yesod Yosef ve-hu Tiqqun Qeri (Frankfurt Oder, 1679) [11a]. 
though we have already clarified the tiqqun related to it in . . Ša'ar Ruah ha-Qodeš . . ., where it is applied to cleanse oneself . . . in order not to enter into geheinom, ... one still needs an additional tiqqun, greater and more effective than the former one ..., which is to restore and revive those wasted drops that entered the qelippot and return them to holiness. ${ }^{17}$

Vital presents here a hierarchy of corrective actions. The first, outlined in $\check{S} a$ ' $a r$ Ruah ha-Qodeš, is typically performed during the period of weekly readings of Exod 1-30, also known as shoba $\underline{b} i$ " $m$. It is associated first and foremost with a number of fasts that are determined by the numerical value of a word associated with the respective $\sin .{ }^{18}$ In the short term, it is intended to ensure the soul's ascent during its nocturnal exit from the body. Viewed over the longer term, it saves the soul from the postmortem period of geheinom. The second type is designed to redeem and revitalize the seeds caught in the realm of the qelippot. The mental concentration techniques (kavvanot) that are needed to accomplish this second process operate on two different planes: they "kill the unclean bodies that host the [fallen] souls and . . . return them to the supernal feminine of holiness (ha-nuqba' ha- 'elyonah de-qedušah)." ${ }^{\prime 19}$ Put differently, the first mode of restorative action relates to the individual realm, rectifying a person's misdemeanor, whereas the second pertains to the cosmic level, aiming to remedy the collapse that constitutes an integral part of the Lurianic concept of creation. ${ }^{20}$ Both of them serve to redeem the lofty, purely masculine souls that, according to Zoharic myth, were created by Adam during the 130 years he was separated from his wife. ${ }^{21}$ From a gender perspective, there is a notable polarization of two females: one demonized in the form of the qelippot, and the other sanctified in the form of the upper female, elevated to the archetype of the "Great Mother," to use Erich Neumann's term. ${ }^{22}$ Both are conceptualized as receptive, and it is ultimately the male kabbalist's actions that determine the destiny of the seed.

Even though the writings attributed to Vital discuss the issue of qeri and wasted seed and offer a variety of penances, they do not contain the prayer supplication that is the subject of this study. This is first found in a text that later became known under the title Limmudey 'Asilut.

${ }^{17}$ Vital, $\check{S} a$ 'ar ha-Tefillah, 207.

${ }^{18}$ Vital, Ša 'ar Ruah ha-Qodeš, 61-62 (and 145-48 for the tiqqunim attributed to Moshe Yonah). Sho $\underline{b} a \underline{b} i$ " $m$ is an acronym derived from the designations of the six weekly Torah portions of Exod 1-30. It also alludes to the "backsliding children" (banim shobabim) mentioned in Jer 3:22 (see Fine, Physician of the Soul, 177-79).

${ }^{19}$ Vital, $\breve{S} a$ ar ha-Tefillah, 207.

${ }^{20}$ See also Gershom Scholem, Sabbatai Sevi: The Mystical Messiah; 1626-1676 (Princeton: Princeton University Press, 2016) 45-46.

${ }^{21}$ Magid, From Metaphysics to Midrash, 59. See also Zohar 1:19b and cf. Wolfson, Venturing Beyond, 174-75.

${ }^{22}$ Erich Neumann, The Great Mother: An Analysis of the Archetype (New York: Pantheon Books, 1963). 


\section{The Tiqqun Qeri Supplication in Lurianic Writings}

The treatise Limmudey 'Așilut was first published in 1850 in Lviv. ${ }^{23}$ However, as Yosef Avivi has shown, it comprises different texts classified as "first-generation" Lurianic materials, namely, traditions recorded by direct students of Luria. For our purpose, the work that constitutes the basis of the second part of Limmudey 'Asilut is of particular interest. ${ }^{24}$ Transmitted from Damascus via Italy, it reached Ashkenaz, where it first became known under the title Hathalat ha-Hokmah. ${ }^{25}$

Hathalat ha-Hokmah is one of the earliest examples - if not the earliest - in which the prayer supplication is recorded. There, it is part of a larger metaphysical discussion on the different types of proselytes. Elaborating on the seven palaces inside the feminine aspect of Malkut in the world of creation, the author of Hathalat ha-Hokmah describes the lowest palace as the "palace of sapphire stone," 26 in which "the angel Tohariel resides, who purifies the souls of the proselytes." 27 These are further divided into three distinct groups. The first consists of souls that stem from the Other Side and were granted permission to attach themselves to holiness. The so-called good souls are generated as a reward for the good deeds of a non-Jew and implanted into the body of his son. The holy spark inherent in these particular souls causes the individual to convert. The second group contains souls that are "oppressed" by qelippat nogah, and the third group is comprised of souls created by a male Jew and a non-Jewish woman who think about each other while having intercourse with their legitimate partners, thereby creating a situation in which the souls, by the sheer power of thought, are intermingled, implanting a holy soul into the son of the non-Jewish woman, who in turn converts. ${ }^{28}$

In all three cases, conversion is considered as the return of a portion of holiness to its natural habitat. In the first case, it constitutes a cross-generational reward for good actions performed by a non-Jew; in the second and third cases, it is an act of redeeming a soul caught by the misconduct of an Israelite male, who either

\footnotetext{
${ }^{23}$ For the tiqqun qeri addendum in print, see Limmudey 'Asilut (Lviv, 1850) 17a-18b and ibid. (Munkács 1897) 25a-b.

${ }^{24}$ See, for example, MS New York JTS 1585, 262a-273a (formerly 15-26). This manuscript in Italian script is an autograph of Menahem Azaria of Fano.

${ }^{25}$ Avivi, Kabbala Luriana, 1:205-7, 305-7, 441-43. The earliest version of the first part of Hathalat ha-Hokmah can be found in MS Jerusalem NLI $4^{\circ} 19,16 \mathrm{a}-45 \mathrm{~b}$ and fols. $46 \mathrm{a}-57 \mathrm{~b}$.

${ }^{26}$ See Limmudey 'Așilut (Lviv, 1850) 17a. On the seventh palace in the Zohar, see Elliot R. Wolfson, Luminal Darkness: Imaginal Gleanings from Zoharic Literature (Oxford: Oneworld Publications, 2007) 228-57, esp. 240-43.

${ }^{27}$ MS New York JTS 1585, 263b. On the angel Tohariel standing at the portal to the seven halls of purity, see Zohar 2:263a (Heykalot Pequdey). On Tohariel purifying souls in the fourth heavenly palace, see Gershom Scholem, "Sidrei de-Shimusha Rabba," in Devils, Demons and Souls: Essays on Demonology by Gershom Scholem (ed. Esther Liebes; Jerusalem: Ben-Zvi Institute, 2004) 116-144, at 123 (Hebrew). See also Elliot R. Wolfson, The Book of the Pomegranate: Moses De Leon's "Sefer ha-Rimmon" (BJS 144; Atlanta: Scholar's Press, 1988) 403.

${ }^{28}$ On "thought"-related transgressions as the gravest form of sin, see also Naftali Bakhrakh, 'Emeq ha-Melek (2 vols.; Jerusalem, 2003) 1:96.
} 
caused the generated soul to be trapped in the realm of the qelippot by means of wasting seed or, by means of impure thoughts, caused it to enter the body of a nonJewish child, who returns it by becoming Jewish. This theory on the origins and preconditions of conversion thus reflects a particularistic worldview in which being Jewish is represented as a divine configuration, and the possibility of becoming Jewish is predetermined by this very constellation. In this context, the addendum quoted at the beginning of the article is applied to offer a strategy for redeeming the souls belonging to the second category, namely, those trapped in the realm of the qelippot. ${ }^{29}$

The earliest extant version of Hathalat ha-Hokmah can be dated to the late sixteenth or early seventeenth century, but the identity of its author remains unknown. Yosef Avivi argues that there are clear indications that the particular manuscript that includes the addendum was composed neither by Israel Sarug nor by Menahem Azaria of Fano (1548-1620). ${ }^{30}$ Ronit Meroz attributes it to "an anonymous kabbalist, who was the first and earliest representative of the Sarugian school. ${ }^{31}$ Be that as it may, the prayer supplication was in fact associated with Israel Sarug at a later stage, as will be shown below.

As already mentioned, Hathalat ha-Hokmah as a whole only became accessible to a wider public due to its incorporation into Limmudey 'Așilut in the midnineteenth century. However, large parts of it were integrated into some of the earliest Lurianic works that appeared in print, the most prominent example being Naftali Bakhrakh's 'Emeq ha-Melek, which was first published in Amsterdam in $1648 .^{32}$ As Moshe Idel has argued, Bakhrakh complained about the neglect of the Lurianic tiqqunim, whose purpose "was to induce a state of repentance, . . . and not to uplift divine sparks to unite divine powers." ${ }^{\prime 33}$ Idel's observation certainly applies to the first gate of 'Emeq ha-Melek, which deals with penitential practices mainly taken from $\check{S}$ a'ar Ruah ha-Qodeš. ${ }^{34}$ In our particular case, however, the primary purpose of the addendum indeed points to a restorative dimension, as it serves as the means to uplift "each and every drop" to its source. This exception is also reflected in the fact that Bakhrakh did not include the prayer supplication in the section that discusses penances of a corrective type. Rather, and in compliance with Hathalat ha-Hokmah, it remained part of the larger discussion about the Throne of Glory in the world of creation.

\footnotetext{
${ }^{29}$ Naftali Bakhrakh refers to this practice in 'Emeq ha-Melek as a type of "penance that replaces evil with good" (ibid., 2:998).

${ }^{30}$ Avivi, Kabbala Luriana, 1:206.

${ }^{31}$ Ronit Meroz, "The Saruk School of Kabbalists: A New Historical Interpretation," Shalem 7 (2002) 151-93, at 157 (Hebrew).

${ }^{32}$ Bakhrakh, 'Emeq ha-Melek, 2:998.

${ }^{33}$ Moshe Idel, “'One From a Town, Two From a Clan': The Diffusion of Lurianic Kabbalah and Sabbateanism; A Re-Examination," Jewish History 7.2 (1993) 79-104, at 92 (see also 103 n. 77, and cf. Naftali Bakhrakh, 'Emeq ha-Melek, [Amsterdam, 1648], 132a-b).

${ }^{34}$ Bakhrakh, 'Emeq ha-Melek, 1:95-102.
} 
In addition to the redaction of works that center around the complex metaphysics of Lurianic doctrine, the demand for systematizing its practically oriented segments increasingly became a major focus. Two of the most prominent and influential examples thereof are Pri 'Es Hayyim, edited by R. Meir ben Yehuda Leib Poppers (ca. 1624-1662), and Me'orot Nathan by Nathan ben David Reuven Shapira of Jerusalem (died 1667). Both compositions were compiled with the intention of organizing the Lurianic materials "that follow no [particular] ordering principle and have no beginning and end," 35 both dedicate large sections to mystical prayer intentions, and both draw from a partly congruent pool of sources. Apparently, the similarities in the form and content of Poppers's and Shapira's compilations led the operators of the Korzec printing press to publish them under the same title. ${ }^{36}$

The highly complex editorial history of Poppers's and Nathan Shapira's writings cannot be discussed in detail here. It shall suffice to say that the manuscript versions vary greatly, some of them comprising materials taken from writings attributed to Vital in particular, while others include traditions associated with the students of Luria in general. ${ }^{37}$ The latter type can be found from the seventeenth century onward, and it usually includes variants of the prayer addendum, as well as additional teachings that are absent in Vital's Eight Gates. ${ }^{38}$ Thus, for example, one of the early versions of Me 'orot Nathan not only offers two different wordings of the tiqqun qeri prayer, but, alongside gematriot that explain the relationship of the divine name $H B^{\prime \prime} V$ (חבר) and the tenth blessing of the Amidah, it also refers to the following interpretation delivered in the name of Nathan Shapira:

The gematria of "gathers the dispersed" 39 amounts to $\check{s} " d$ (i.e., 304), because demons (šedim) take all the drops of [the semen] and create other demons from them as is known, and by means of the name $\left[H B^{\prime \prime} V\right]$, he will kill them, returning all the drops to the place from which they emerged. ${ }^{40}$

The theme of the creation of demons - framed in the Lurianic motif of the divine sparks being trapped in the realm of the husk after the breaking of the vessels -

\footnotetext{
${ }^{35}$ Meir Poppers, introduction to Derek 'Es Hayyim (Korzec, 1782) 1c (and see also 1d); Nathan Neta Shapira, Me'orot Nathan, MS New York JTS 1593, 2a (qtd. in Avivi, Kabbala Luriana, 2:704-5).

${ }^{36}$ Avivi has described the 1782 edition of Pri 'Es Hayyim as a heavily edited version of Me'orot Nathan (see idem, Kabbala Luriana, 2:649 and 2:705). The two versions of Meir Poppers's Pri 'Es Hayyim were published in 1785 and 1786, respectively. The different versions caused some confusion among later editors. In the foreword to the Dubrowno print from 1803, the proofreader Moshe Ben Meir explicitly refers to these discrepancies, stating that he combined the 1782, 1785, and 1786 Korzec prints.

${ }^{37}$ The earliest extant copy of Poppers's Pri 'Es Hayyim is dated to 1651 (see MS Jerusalem $4^{\circ} 6720$; for the discussion of the Amidah's tenth blessing, see ibid., 116a-b. See also Avivi, Kabbala Luriana, 2:638, 2:649 no. 786). It is noteworthy that this particular version does not include the prayer supplication under investigation.

${ }^{38}$ See, e.g., Nathan Shapira, Me'orot Nathan, MS Oxford, Bodleian Library 1850, 233a-235a.

39 מקבץ נדחי.

${ }^{40}$ Nathan Shapira, Me'orot Nathan, MS Oxford, Bodleian Library 1850, 234b-235a. See also Pri 'Eș Hayyim (Korzec, 1782) 52a and ibid., (Dubrowno,1803) 58a.
} 
developed into one of the major points of reference in later strategies dealing with sexual pollution. More importantly, the manuscripts that exhibited a compiling character ultimately formed the basis of the printed editions of Pri 'Es Hayyim. This development nicely illustrates how in this particular case, variations of Lurianic traditions belonging to the same conceptual field were perceived as complementing each other rather than promoting one single authoritative form of Luria's teachings. This is an example of what Agata Paluch has described in a different context as "an integrative, all-inclusive approach" that attributes "equal status to all of the mystical texts . . . free from the constraints of any "master narrative." "'41

While the provenance of the prayer supplication remained unnamed for almost two centuries, it was eventually associated with Israel Sarug toward the end of the eighteenth century. In the printed version of Pri 'Es Hayyim from 1785, it reads:

And R' Israel Sarug, a student of the Ar"i, used to recite the following prayer: May it be Your will that you shall receive each and every drop of semen that came out of me in vain, which did not [serve to fulfil a positive] commandment-whether under coercion or willingly; whether in thought or deed. Furthermore, all of the souls imprisoned within the qelippot nogah ... shall be vomited out of her belly ... and returned to God, which is holiness, ${ }^{42}$ for the sake of Your great name $\left.\left[H B^{\prime \prime} V\right]\right]^{43}$

The theory on the proselytes' souls is entirely absent here. Moreover, the version of the prayer itself differs, as it explains in some detail the imprisonment of the drops as an act of swallowing and their release as an act of vomiting "out of the belly of the qelippah," a process that is only hinted at in the earlier versions included in Hathalat ha-Hokmah and 'Emeq ha-Melek. In order to obtain a coherent analogy between the Lurianic theory of wasted seed and the account of Job 20:15, the biblical prooftext was altered and restructured into three rather than two units. Instead of reading "The riches he swallows he vomits; God empties it out of his stomach," the present passage distinguishes between the act of swallowing, the act of vomiting, and the act of returning the seed to its rightful owner. The allegorical interpretation is therefore enabled by means of a literal rendering of the biblical verse. ${ }^{44}$ The notion of revealing a hidden connection between the biblical wording

${ }^{41}$ Agata Paluch, Megalleh 'Amuqot: The Enoch-Metatron Tradition in the Kabbalah of Nathan Neta Shapira of Kraków (1585-1633) (Los Angeles: Cherub Press, 2014) 28 and 21.

42 "Holiness" is usually identified with the divine feminine, or Malkut. See, e.g., Moshe Cordovero, Pardes Rimmonim, gate 23, chapter 19 (Jerusalem, 2000) 376.

${ }^{43}$ Meir Poppers, Pri 'Es Hayyim (Korzec 1785) 52a. On the question of Sarug as a student of Luria, see Gershom Scholem, "Israel Sarug_Disciple of Luria?," Zion 5 (1940) 214-43 (Hebrew) (reprinted in Lurianic Kabbalah: Collected Studies by Gershom Scholem [ed. Daniel Abrams; Los Angeles: Cherub Press, 2008] 295-329); Ronit Meroz, "R. Yisrael Sarug_Luria's Disciple: A Research Controversy Reconsidered," Daat 28 (1992) 41-50 (Hebrew).

${ }^{44}$ In the given context, the verb יורישנו is usually rendered figuratively, as God "casting out" the riches, and not in the literal sense of the root יר in the Hif'il as to "take into possession" or "to return to one's rightful owner." 
and the prayer, as well as the kabbalistic doctrine of wasted seed, is further amplified in later receptions of the rectification of this wastage.

\section{Kabbalistic Handbooks and Anthologies of Kabbalistic Liturgy}

Compilations such as Pri 'Es Hayyim and Me'orot Nathan were only a prelude to a distinct genre that made kabbalistic ideas accessible to a much larger audience, and these books almost always include the tiqqun qeri supplication under investigation. Poppers himself partook in this endeavor by authoring 'Or Saddiqim, a work later published under the title 'Or ha-Yašar. ${ }^{45}$ Other examples thereof are charm books (segulot ve-refu'ot) that specifically deal with the rectification of sexual pollution, such as Yesod Yosef by Joseph ben Solomon of Posen (1601-1696), or Zekariah ben Jacob Simner's Sefer Zekirah ve- 'Inyyanei Segulot. ${ }^{46}$ One of the most successful anthologies of kabbalistic liturgy was undoubtedly Ša 'arei Sion by Nathan Neta Hanover (ca. 1610-1683), which has been printed in over 120 editions since its first publication in Prague in 1662. ${ }^{47}$ In his fashioning of a collection of various kabbalistic prayer intentions, unifications, and supplications, it is not surprising that Nathan Neta Hanover also reproduced the addendum in the tiqquney tefillot section of his book.

In general, the prayer's embedment in anthologies of kabbalistic liturgy reflects a continued shift in which the metaphysical and technical discussions of the rationale behind the tiqqun fade into the background, while their adaptations to the needs of everyday life are brought to the fore. This tendency is also documented by the rather brief instructions that accompany the prayer. Thus, for example, Nathan Neta Hanover merely notes, prior to the actual wording of the blessing, that the readers should recite it because "it is a rectification of sexual pollution." 48 It is noteworthy in this context that unlike the exercises outlined in $\breve{S} a$ 'ar Ruah ha-Qodeš, a great deal of these kabbalistic handbooks hardly ever mention more radical forms of penance such as lashing, wearing sackcloth, and the like, which suggests that the authors were attempting to promote practices suitable for large sections of the community. ${ }^{49}$

Utilizing the addendum as a universal tool for avoiding sexual pollution added a prophylactic dimension to the formerly exclusively restorative notion. This

\footnotetext{
${ }^{45}$ See Meir Poppers, 'Or Șaddiqim (Hamburg, 1690), no. 41 [55-56]; ibid., (Warsaw, 1889) 22-23; 'Or ha-Yašar (Amsterdam, 1709) 18b; ibid., ed. Hayyim Yosef Waldmann (Jerusalem, 1981) 268.

${ }^{46}$ Solomon ben Solomon of Posen, Yesod Yosef (Frankfurt Oder, 1679); Zekariah ben Jacob Simner, Sefer Zekirah ve- Inyyanei Segulot (Hamburg, 1709).

${ }^{47}$ Nathan Neta Hanover, Ša 'arei Șion (Prague, 1662). For a comprehensive treatment of Ša 'arei Sion, see Assaf Nabarro, “Tiqqun': From Lurianic Kabbalah to Popular Culture” (PhD diss., BenGurion University of the Negev, 2006) 88-139 (Hebrew). See also Yehuda Liebes, Studies in Jewish Myth and Jewish Messianism (Albany: State University of New York Press, 1993) 7; Hundert, Jews in Poland-Lithuania, 130.

${ }^{48}$ Hanover, Ša 'arei Șion, [36 (my counting)]; ibid., (Amsterdam, 1671), 29a. See also Tiqqun Šlomo (Sulzbach, 1758) 21a for a later adaptation of this formula and the prayer addendum.

${ }^{49}$ See Fine, Physician of the Soul, 180.
} 
transformation is particularly witnessed in a small yet significant modification of the wording in $\check{S}$ a arei Șion. Whereas the previous examples referred to the transgression in the past tense, Nathan Neta Shapira uses the present tense, making a general allusion to "each and every drop of seed that exits" the male organ. ${ }^{50}$ The prophylactic orientation of the addendum opened the way to new forms of short prayer that were associated with the bedtime Shema, such as the one printed in Benjamin Beinsh ha-Kohen's Sefer Šem Tob Qațan (Sulzbach, 1704) in which the individual pleads to be spared from sexual pollution, worldly desires, and vain thoughts and asks God to grant that he will not have an erection during the night, as well as more misogynistic formulations that can be found in works such as Șevi Hirsh ben Hayyim of Fürth's Liqqutey Șevi (Wilhermsdorf, 1738). ${ }^{51}$ In other instances, recommendations such as not to speak after the recitation of the addendum were added, a notion somewhat similar to strategies applied in an early Christian monastic setting. ${ }^{52}$

A further example that illustrates the great impact of $\breve{S}$ a 'arei Șion in an Ashkenazi context is Yehiel Michel ben Avraham Epstein's (died 1706) Qișur Šney Luhot haBrit. ${ }^{53}$ In his concise set of instructions for how to overcome one's sexual desire both physically and mentally, Epstein recommends, inter alia, that one should "recite that very prayer printed in $\breve{S} a$ 'arei Sion during the blessing 'Blow into the great Shofar' of the eighteen benedictions." ${ }^{154}$ For those who are not able to fall asleep, he recommends the following mantra-like exercise:

He shall [repeatedly?] say the verse "Light is sown for the righteous, joy for the upright" (Psalm 97:11) and focus on the last letters of the words "light" ('or), "sown" (zarua), and "righteous" (saddiq), [in reverse order, namely,] $q r^{\prime \prime} a$ ' [that is the root of the verb] "to tear" [apart] (liqroa) the qelippot by means of the name $Q R^{\prime \prime} A^{\prime}$, and to lift up those drops [of semen] spilled in vain from the qelippot. [Furthermore], he shall focus on the last letters of "for the upright" (u-le-yišrei), "heart" (leb $)$, [and] "joy" (śimhah), [namely, yod,

${ }^{50}$ 'יצאה' in Hathalat ha-Hokmah (MS New York JTS 1585, 264a) and 'Emeq ha-Melek (Amsterdam, 1648) 170c. יצא in Pri 'Eș Hayyim (Korzec, 1785) 52a. In Ša'arei Șion (Prague, 1662) [36 (my counting)]; ibid., (Amsterdam, 1671) 29b: ויוא יו'.

${ }^{51}$ Benjamin Beinsh ha-Kohen, Sefer Šem Tob Qațan (Sulzbach, 1704) 7b (on the causes and effects of sexual pollution during sleep, see ibid., 4b), and Pachter, "Shmirat Habrit," 224; Șevi Hirsh ben Ḥayyim of Fürth (or Wilhermsdorf), Liqqutey Șevi (Amsterdam, 1809) 8b.

${ }^{52}$ See, e.g., John Climacus, who stated that "the best strategy against pollution is to fall asleep while saying the 'Jesus Prayer'" (Ladder of Ascent [New York: Paulist, 1982] 172, 178); Dyan Elliott, Fallen Bodies: Pollution, Sexuality, and Demonology in the Middle Ages (Philadelphia: University of Pennsylvania Press, 1999) 17.

${ }^{53}$ Sefer Qișur Šney Luhot ha-Brit was first printed in Fürth in 1693. The popular expanded version (mahadura batra) was published there in 1697 (see Marvin Heller, The Seventeenth Century Hebrew Book [2 vols.; Leiden: Brill, 2011] 2:1232-33).

${ }^{54}$ Yehiel Michel ben Avraham Epstein, Qișur Šney Luhot ha-Brit 'im Mahadura Batra (Jerusalem, 1960) 71-72. 
bet, and heh, whose numerical value] in gematria [amounts to] seventeen, [which is identical to the] amount of "good" (tob $\underline{b})$ which [in sum corresponds to] the gematria of the small number of the Tetragrammaton. ${ }^{55}$

\section{Prayer Books and Mahzorim}

Yehiel Michel ben Avraham Epstein's case is not only decisive because of his compilation of a condensed version of Isaiah Horowitz's monumental work Šney Luhot ha-Brit. He also edited a highly influential prayer book four years after the Qisur saw the light of day. Unlike the decidedly technical kabbalistic prayer books that included detailed kavvanot, yihudim, and lengthy quotations from the Lurianic corpus, Epstein's efforts also mark the attempt to make kabbalistic practices accessible to nonelitist circles. According to his testimony, Epstein created his Siddur Seder Tefillah Derek Yešarah following his realization that "the majority [of Jews who live] in the settlements and villages do not have a leader or rabbi at their disposal that could guide them [properly]. ${ }^{56}$ With this in mind, he reproduced all kinds of explanatory notes from kabbalistic, moralistic, and legalistic writings that would provide the reader with the information he considered necessary for correct observance. One of these additions is the short prayer for the rectification of wasted seed. Epstein further complemented the Hebrew text with a Yiddish translation-commentary, which significantly expanded the potential readership.

Siddur Seder Tefillah Derek Yešarah was first published in Frankfurt am Main in 1697. In the subsequent four decades, seven editions followed. ${ }^{57}$ It was, however, with the Amsterdam print in 1734 that Epstein's prayer book experienced its final breakthrough. It became the blueprint for numerous editions, for both the Sephardi and the Ashkenazi rites. At the beginning of the nineteenth century, one can still find siddurim modeled after the Amsterdam edition of 1734 in German cities such as Nuremberg or Karlsruhe. ${ }^{58}$

In addition to the associations with the eighteen benedictions and the bedtime Shema, a more verbose version of the addendum was incorporated into mahzorim as part of the mussaf or additional prayer for Shabbat, the new month, the new year, and the Day of Atonement. ${ }^{59}$ It is most likely that the thematic and textual

\footnotetext{
${ }^{55}$ Ibid. In gematria, the "small number" or cross-sum of the word tob $(9+6+2)$ is 17 , like the cross-sum of the Tetragrammaton $(\mathrm{YHWH}=1+5+6+5=17)$.

${ }^{56}$ Yehiel Michel ben Avraham Epstein, Siddur Seder Tefillah Derek Yešarah (Frankfurt am Main, 1697) title page; idem, Qișur Šney Luhot ha-Brit, introduction (in Heller, Seventeenth Century Hebrew Book, 2:1233).

${ }^{57}$ It was reprinted in Frankfurt am Main four times $(1707,1714,1723,1733)$, twice in Frankfurt Oder (1703, 1728), and once in Jessnitz (1720).

${ }^{58}$ Seder Tefillah šel Mhr"r Mikel Epstein (Nuremberg, 1768); Seder Tefillah ke-Minhag ha'Aškenazim (Karlsruhe, 1804-05).

${ }^{59}$ Hundert, Jews in Poland-Lithuania, 131, refers to a manuscript that includes the very same prayer (YIVO Institute in New York, RG 242; copy of the original document in the Personenstandsarchiv Koblenz: RSA 3 906, 21-22).
} 
affinities between the "who performed miracles to our forefathers" section of the prayer and the tenth blessing of the Amidah provided the basis for this third type. Both revolve around the themes of exile and redemption. More specifically, both use identical terms to address the ingathering of the dispersed of Israel, which in Lurianic hermeneutics was used as an important prooftext for establishing a link between the former and the redemption of the trapped drops of semen from the qelippot, as well as the liberation of the fallen divine sparks from the husks. ${ }^{60}$ This connection had already been highlighted by Nathan Shapira of Jerusalem, who wrote that

the penultimate letters of the words "together from the four corners" ${ }^{1}$ form the name $H B^{\prime \prime} V$. In sum, the [numerical value of both the letters and the] vowel signs amount to seventy-two, as [the name $H B^{\prime \prime} V$ ] is one of the seventy-two names [derived from the biblical verses of Exodus 14:19-21 that begin with the words] "and he removed," "and he came," "and he stretched out." [The name's] remedy is to remove holy sparks from the husks. . . And all the sparks are called Israel, because the six extremities ${ }^{62}$ are called Israel. ${ }^{63}$

Nathan Shapira's emphasis on collecting as an act of reestablishing the collective is also reflected in the language of the addendum. In an early testimony in printthe anonymous allegedly Sabbatean work Hemdat Yamim published in Izmir in 1732 - the author reports that his teacher requested that a certain penitent recite the following supplement, for the transgression of wasting seed "prolongs the exile and conceals the quality of the light of the moon that is like the light of the sun": ${ }^{64}$

May it be the will before you, Lord, our God and [God] of my fathers, that each and every drop of qeri that I wasted ..., as well as the souls oppressed by the qelippot that are scattered in the four corners of the earth and the souls that wander around naked, ${ }^{65}$ by the power of the holy name $B Y^{\prime \prime} T^{66}$ and the holy name $H B^{\prime \prime} V$, that You shall rescue them [from] the qelippah and return them to the place of holiness. It shall be fulfilled . . . as it is written "that then the Lord thy God will turn thy captivity ... and will return and gather thee

${ }^{60}$ On "exile" and "redemption" as the two poles of the Lurianic system, see Scholem, Sabbatai Sevi, 22-44.

יחד מארבע כנפות 61.

${ }^{62}$ Nathan Shapira equates the six extremities with the six parșufin, or configurations, 'Attiq, 'Arik 'Anpin, 'Abba, 'Imma, Ze ir 'Anpin, and Nuqba'. The use of the name "Israel" also hints at the unitive understanding of Israel as one body, represented by the Sefirah of Tif'eret.

${ }^{63}$ MS Oxford, Bodleian Library 1850, 233b; and see Pri 'Es Hayyim (Korzec, 1782) 52a.

${ }^{64}$ Hemdat Yamim (3 vols.; Izmir, 1732) 2:17a. On the myth of the waning of the moon in $b$. Hul. 60b, see Liebes, Studies in Jewish Myth, 47-48.

${ }^{65}$ The Aramaic phrase דאזלין ערטילאין (lit., "those who walk around naked") depicts the condition of the souls of sinners, which wander around in the world of chaos until they are rehabilitated. See, e.g., Tiqquney ha-Zohar (ed. Reuven Margaliot; Jerusalem: Mossad ha-Rav Kook, 1978) 23 b.

${ }^{66}$ The name $B Y^{\prime \prime} T$ (בי"ט) is derived from the words "who performed miracles" (מי שעשה ניסים), the first letters forming the acrostic שמ"ן (oil), that by means of 'at-baš-a technique that replaces the first letter of the alphabet with the last one, the second with the second to last one, and so forth-is transformed into $B Y^{\prime \prime} T$. See also Bakhrakh, 'Emeq ha-Melek, 2:1002. 
from all the peoples, whither the Lord thy God hath scattered thee. If any of thine that are dispersed be in the uttermost parts of heaven, from thence will the Lord thy God gather thee, and from thence will He fetch thee" (Deuteronomy 30:3-4), and hasten our redemption, the redemption of the world, "to join together the tent that it might be one" (Exodus 36:18). ${ }^{67}$

The soteriological motif articulated in Hemdat Yamim, that the fulfillment of a future unitive reality depends on human interventions, is amplified in the many variants of this particular addendum in early modern prayer books. According to the version in Siddur Mišnat Hasidim printed in Zolkiew in $1744,{ }^{68}$ wasted seed is not only considered the reason for the continued state of exile but is also regarded as its primary cause. By virtue of this transgression, "souls wander around naked among the gentiles, our city was destroyed and our Temple deserted, our honor was exiled and our glory was taken from the house of our lives." ${ }^{69}$ Furthermore, Siddur Mišnat Hasidim, as well as many other later examples, stresses the collective dimension of the restorative process, atoning for both the drops spilled individually and those "who came out of all [male members of] Israel" in general. ${ }^{70}$

Toward the end of the eighteenth century, one can find the extended version of the prayer supplication in the liturgical handbooks Sansan le-Ya'ir and Kaf 'Ahat by the kabbalist and bibliophile Hayyim Yosef David Azulai (1724-1806). ${ }^{11}$ This means that we are not dealing with an exclusively Ashkenazi phenomenon here. As these, as well as the example of Hemdat Yamim, show, it is also evidenced in Ottoman and Italian contexts. Moreover, it is worth mentioning that the centrality of the Lurianic association of wasting seed with the primordial sin of Adam in Sabbatian literature certainly added to the wide dissemination of the supplication. ${ }^{72}$ While Sabbatian texts ascribe the task of rectifying Adam's primordial sin to the messiah himself, as a subversive act of releasing the sparks caught by the qelippah by means of hypernomian actions, the prayer addendum serves a similar purpose, urging every male member of the community of Israel to redeem their portion of wasted seed from the qelippah. ${ }^{73}$

${ }^{67}$ Hemdat Yamim (Izmir 1732) 2:17a-b.

${ }^{68}$ Not to be confused with Rafael Emanuel Ḥay Ricci’s (1688-1743) Mišnat Hasidim (Amsterdam, 1727).

${ }^{69}$ Siddur Mišnat Hasidim (Korzec 1785) 84b.

${ }^{70}$ Ibid.

${ }^{71}$ Hayyim Yosef David Azulai, Sansan le-Ya'ir (Livorno, 1790); ibid., Kaf 'Ahat (Livorno, 1802), republished in Seder 'Avodah 'Avodat ha-Qodeš (Jerusalem: Ahavat Shalom, 2012). For the addendum, see 180 (in Kaf 'Ahat) and 238-39 (in Sansan le-Ya'ir).

${ }^{72}$ See Wolfson, Venturing Beyond, 191-92, 298, and 183.

${ }^{73}$ Ibid., 183. On hypernomianism, see also ibid. 


\section{Converts, Humanists, and Jesuits: Inner-Christian and Jewish-} Christian Debates

The more popularity the different variants of the prayer addenda for the rectification of wasted seed gained, the more they became subject to dispute. The critical positions were part of ongoing inner-Christian and Jewish-Christian polemics, on the one hand, and inner-Jewish debates in the aftermath of Sabbatianism and the formation of Hasidic, Maskilic, and Orthodox Judaisms, on the other.

The accusations that Jewish discussions about the creation of demons constitute a theological polemic against Christians and Christianity go back to the early sixteenth century, and converts to Christianity played an essential part in this. Thus, the Dominican theologian and convert from Judaism Johann Pfefferkorn (1469-1521) claims in The Enemy of the Jews that "if a Christian comes to a Jew, he receives him and says: Seind wilkum, meaning 'Devil, be welcome', for seth means devil." 74 These pseudolinguistic observations caused an inner-Christian debate between Dominicans and humanists. Johannes Reuchlin (1455-1522), known for his positive attitude toward Jewish literature, ${ }^{75}$ responded to Pfefferkorn in his Report about the Books of the Jews, writing:

I pass over in silence other words in the same booklet, which have perhaps not been rendered correctly in German out of ignorance, as when the Jews are said to receive a Christian into their house or greet him in the street, saying "Seit willkum." The author of the booklet states that they say "Sed willkum," which according to him, means "Devil, welcome." But according to correct usage this cannot be, for של, the word for "devil" is written with a dot on the right side of the letter "s." For this reason it is pronounced "sh," "shed." If they said "Shed willkum" any peasant would notice that this is different from "Seit willkum," for "shed" sounds quite different from "seit." This is nonsense, therefore, and child's play, and need not concern us in this report. ${ }^{76}$

Reuchlin's apologetic approach goes even further, to the extent that he attempted to tone down the Zoharic myth of Adam spilling his seed during his 130-year separation from his wife, during which time he impregnated impure female spirits and engendered spirits and demons called "afflictions of the children of Adam" (2 Sam 7:14). ${ }^{77}$ In his De arte cabalistica, he offers a metaphorical reading, arguing that Adam did "not actually produce demons and changelings as some of the vulgar and irreverent have falsely claimed. Simply, they were men with evil dispositions,

\footnotetext{
${ }^{74}$ Johann Pfefferkorn, Hostis judaeorum hic liber inscribitur, qui declarat nequicias eorum circa usuras et dolos etiam varios (Cologne: Henricus de Nussia, 1509) 4r (my counting).

${ }^{75}$ See, e.g., G. Lloyd Jones, introduction to Johann Reuchlin, On the Art of the Kabbalah-De Arte Cabalistica (trans. Martin and Sarah Goodman; New York: Abaris Books, 1983) 12-16.

${ }^{76}$ Johannes Reuchlin, "Ratschlag ob man den Juden alle ire bücher nemmen / abthun unnd verbrennen soll," in idem, Augenspiegel ([Tübingen]: [Anshelm], [1511]) 5v. English translations in Erika Rummel, The Case against Johann Reuchlin: Religious and Social Controversy in SixteenthCentury Germany (Toronto: University of Toronto Press, 2002) 56 and 91.

${ }^{77}$ See Zohar 2:231b, 1:54b; Magid, From Metaphysics to Midrash, 55-71.
} 
though nothing is bad except through vices and evil spirits": they "seemed more like a crop of devils than men, such was their malice and wickedness." 78 Against the background of the previous discussion, it is obvious that Jewish kabbalists would not necessarily share Reuchlin's opinion in this particular case.

Pfefferkorn's attacks and false allegations are only one example of the increasingly popular genre of ceremonial literature that set the tone for Christian polemical attitudes toward Judaism for the next centuries. Jewish prayer, for example, was depicted in these works as a subversive force and as a "real threat to Christian society," as Elisheva Carlebach has comprehensively shown. ${ }^{79}$ Pfefferkorn himself translated segments of the siddur into German, and Antonius Margaritha (ca. 1492-1542) included large portions of the prayer book in his Der gantz jüdisch Glaub in order to reveal anti-Christian sentiments hidden in it. ${ }^{80}$ Toward the end of the seventeenth century, Johann Andreas Eisenmenger (1654-1704) recalls in his Entdecktes Judentum that in 1681, he went to see the Ashkenazi chief rabbi of the Amsterdam community, David Aryeh Leib of Lida (ca. 1632-1697), to dispute about matters of religion. According to Eisenmenger, the rabbi tried to prove that the king of the devils, Samael, ruled over Christianity. ${ }^{81}$

In the emotionally charged atmosphere of prejudice and mistrust, the highly popular anthology of kabbalistic liturgy, $\breve{S}$ a 'arei Sion, came under attack. Following the publication of the 1705 Dyhrenfurth duodecimo edition commissioned by a Jew from Moravia named Markel, ${ }^{82}$ Shabbtai ben Joseph Meshorer Bass (1641-1718), the founder of Hebrew bibliography and the owner of the Dyhrenfurth printing press, was arrested based on the accusations of the Jesuit father Franciscus Kolb that he was disseminating blasphemous anti-Christian doctrines. ${ }^{83}$ Among the charges against Bass preserved in the trial records of the Wrocław court, ${ }^{84}$ it is stated inter alia that $\breve{S}$ a arei Șion includes "various disgraceful things about the

\footnotetext{
${ }^{78}$ Reuchlin, On the Art of the Kabbalah, 75; and idem, De Arte Cabalistica Libri Tres (ed. WiduWolfgang Ehlers et al.; Stuttgart: Frommann-Holzboog, 2010) 90-91 (Latin-German).

${ }^{79}$ See Elisheva Carlebach, Divided Souls: Converts from Judaism in Early Modern Germany, 1500-1750 (New Haven: Yale University Press, 2001) 180-81.

${ }^{80}$ Antonius Margaritha, Der gantz jüdisch Glaub (Augsburg: Steiner, 1530).

${ }^{81}$ Johann Andreas Eisenmenger, Entdecktes Judenthum (2 vols., Frankfurt, 1700) 1:843; and Elisheva Carlebach, “'Ich will Dich nach Holland schicken . . .'Amsterdam and the Reversion to Judaism of German Converts," in Secret Conversions to Judaism in Early Modern Europe (ed. Martin Mulsow and Richard H. Popkin; Brill's Studies in Intellectual History; Leiden: Brill, 2004) 51-69, at 62-63.

${ }^{82}$ See Ludwig R. Oelsner, Sabbathai Bassista und sein Prozess. Nach gedruckten und ungedruckten Quellen (Leipzig: Oskar Leiner, 1858) 14 and particularly 20 n. 10.

${ }^{83}$ Bass printed $\breve{S}$ 'arei Sion in 1689, 1693, and 1705. On Bass's printing activities in general, see Magdalena Bendowska, "Shabbetai Bass: Author, Bibliographer, and Editor," Kwartalnik Historii Zydów 247 (2013) 473-93, esp. 488-492.

${ }^{84}$ Provinzialarchiv "Fürstentum Breslau, V (Polizei), Untersuchung über das von dem jüd. Buchdrucker Sabbathi Bachiu zu Dyrenfurth gedruckte Büchlein Schare Tzion 1712” (published in Oelsner, Sabbathai Bassista, 18-35).
} 
creation of devils," understood as an affront to Christianity. ${ }^{85}$ Bass defended himself by pointing out that such an opinion "is laid down by the rabbis and is not of any concern to the Christians." 86 The independent assessment presented to the court, written by Gottfried Pohl, is, however, more telling. Pohl, a Hebrew teacher at the Gymnasium St. Elisabeth in Wrocław, not only offers a Latin translation of the tiqqun qeri supplication, ${ }^{87}$ but also explains that "Jews who have sinned 'carnally' (peccatis carnis), 'by means of sexual pollution' (pollutionibus), or 'by means of a reckless vow' (temerariis votis $)^{88}$ are accustomed to asking for forgiveness in this fashion." 89 Furthermore, he clarifies that the multiplication of external evil powers does not refer to Christians but to nonhuman beings, stating in compliance with the above-quoted Vitalian notion that wasting seed does not create "corporeal bastards in this world" but causes damage in the divine realm..$^{90}$ Thanks to Pohl's report, Bass was not found guilty by the Wrocław court.

Even though the trial did not have an impact on the wider popularity of $\check{S} a$ 'arei Sion, one can still see the effect it had in Eastern Europe in the following decades. It was not reprinted in Dyhernfurth until 1782. Furthermore, and apart from the serious consequences for Bass in the event of a conviction, it seems that here, also, we are dealing primarily with an inner-Christian debate on the prerogative of interpretation of Judaism fought between the Jesuit Kolb and the Protestant scholar Pohl. Kolb, in addition to his own misreading, seems to have taken up the biased representations of Jewish rites and customs found in ceremonial literature, publicly denouncing and taking extreme actions against an individual who printed a work that was already widely disseminated at that time. Pohl, on the other hand, shows an intimate knowledge of Jewish sources.

Around the same time, in 1717, the Christian pietist Johann Jakob Schudt (1664-1722) wrote in his polemical work Jüdische Merckwürdigkeiten (Jewish Curiosities) that the Jews of Frankfurt would "firmly believe that if a man's seed escapes him, it gives rise . . . to evil spirits." ${ }^{91}$ Even as late as in 1939, the reform rabbi Joshua Trachtenberg mentions in his Jewish Magic and Superstition that "it was generally agreed that man's nocturnal emissions often result from the efforts of the demons to arouse his passions, and that these provide the seed from which the hybrid offspring are born." 92

${ }^{85}$ Oelsner, Sabbathai Bassista, 22-23.

${ }^{86} \mathrm{Ibid}$

87 “([U]t cum venia haec memorare liceat), de generatione daemonum ex guttis spermatis humani, extra ordinarium feminae vas, s. voluntarie, s. involuntarie profusi” (ibid., 28-29).

${ }^{88}$ Probably in the sense of the Hebrew neder, i.e., a promise made to God to perform some deed (see, e.g., in Gen 28:20 or Num 30:3).

${ }^{89}$ Oelsner, Sabbathai Bassista, 30.

${ }^{90}$ Ibid., 31.

${ }^{91}$ Johann Jakob Schudt, Jüdische Merckwürdigkeiten (4 vols.; Frankfurt 1717) 4:43 (appendix); Gershom Scholem, On the Kabbalah and Its Symbolism (New York: Schocken Books, 1969) 156.

${ }^{92}$ Joshua Trachtenberg, Jewish Magic and Superstition: A Study in Folk Religion (New York: Behrman's Jewish Book House, 1939; repr., New York: Atheneum, 1982) 51. 


\section{Hasidim, Maskilim, and Talmudists: Inner-Jewish Polemics}

Among the multifaceted characteristics of the emerging Hasidic movement in Eastern Europe, two tendencies are particularly striking in relation to the prohibition of wasting seed. On the one hand, the followers of Israel ben Eli'ezer (ca. 1698-1760), the Ba'al Šem Țov (Besht), appropriated the highly technical and elaborate Lurianic prayer rite (nusah ha-'Ar"i ) from the outset..$^{93}$ Needless to say, the acceptance of Luria's version among the Besht's followers did not happen in a vacuum. As Amiel Vick argued, members of the famous Brody kloyz, as well as ascetically inclined individuals conventionally termed "old hasidim," would pray with Luria's mystical intentions, indicating a strong sense of elitism. ${ }^{94}$ It is therefore no surprise that members of the kloyz strongly opposed the adoption of the nusah

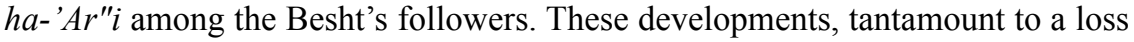
of the kloyz's hegemonic position, manifest themselves in the Brody Herem of 1772, in which Beshtian Hasidim were accused of praying according to the prayer book of the 'Ar"i and ridiculing it, an allegation that eventually led to a general resolution to prohibit the unsupervised use of the Lurianic rite.

On the other hand, and in stark contrast to the approbation of highly esoteric materials, the use of sermons and storytelling as a means for conveying moral teachings to the community of followers opened the possibility of integrating Zoharic and Lurianic concepts of sexual (im)purity into their educational mission and the practice of everyday life. This development is certainly not novel to Beshtian Hasidim either, and we do know of earlier prominent examples, such as the tale of an individual who hid his demon mistress and their offspring in the basement of his house, told in Șevi Hirsh Kaidanover's popular musar book Qav ha-Yašar. ${ }^{95}$ However, it seems that the mutual interference of elitist and mainstream bodies of knowledge led to an intensification of the visual imagery, manifested in the elevation of the exemplary "virtuous woman," on the one hand, and a more radical demonization of the feminine epitomized in the form of Lilith, the snake, or the qelippah, on the other. ${ }^{96}$ It should suffice to give one short example that illustrates how the integration of narrative elements affected the Hasidic nusah ha-'Ar"i. An eighteenth-century manuscript copied by Hirsch Ben ha-Rav Rabbi Yehezkel includes the following version of the addendum to be recited together with the tenth blessing of the Amidah:

${ }^{93}$ On the formation of the Lurianic prayer book, see Pinchas Giller, Shalom Shar'abi and the Kabbalists of Beit El (Oxford: Oxford University Press, 2008) 27-28; Menachem Kallus, "The Theurgy of Prayer in the Lurianic Kabbalah" (PhD diss., The Hebrew University of Jerusalem, 2002); Amiel Vick, “'Through Which All of Israel Can Ascend': On R' Shneur Zalman of Lyady’s Composition of Nusah Haari" (MA thesis, The Hebrew University of Jerusalem, 2012) 4 (Hebrew).

${ }^{94}$ Vick, "Through Which All of Israel Can Ascend," 5. On the label "hasidim of the old type," see Immanuel Etkes, Ba 'al Hashem: The Besht; Magic, Mysticism, Leadership (Jerusalem: Salman Shazar Centre, 2000) 207-16 (Hebrew).

${ }^{95}$ Șevi Hirsh Kaidanover, Qav ha-Yašar (Lublin, 1925) ch. 69, 118b-119a.

${ }^{96}$ See Wolfson, Venturing Beyond, 148-49. 
Direct your thought to the name . . HB" $V, \ldots$ and by the power of this name, you shall discharge each and every drop of semen wasted from all the sons of Israel .... and the souls oppressed by the qelippot of the qelippah so that they can return to holiness. And this is the [meaning] of "The riches he swallows he vomits; God empties it out of his stomach" (Job 20:15) ${ }^{97}$ and they shall all return to the belly of the God-fearing woman, that is the feminine [aspect within the attribute of] holiness (nuqba' de qedušah). ${ }^{98}$

Whereas the previous examples would usually only quote the first part of Job 20:15, the author of this particular manuscript copies the entire verse and deliberately changes the suffix from masculine to feminine. Similar to the version in Pri 'Es Hayyim, he adjusts the biblical reference of vomiting out riches to the "belly" of the female qelippah. The minor textual intervention also serves as a basis for juxtaposing the demonic and the sanctified feminine, and the prayer as a trigger to transfer the seed and souls from the realm of impurity to holiness. Furthermore, by explicitly referring to the "womb of the god-fearing woman," the author alludes to the Zoharic association of Binah as the soul-engendering womb, ${ }^{99}$ as well as to the figuration of forgiveness as returning to the womb duly mentioned by Elliot Wolfson. ${ }^{100}$

The Besht's followers were also challenged within the scope of storytelling, particularly from the side of the Maskilim. As a general background, it is worth mentioning that according to a tradition transmitted in the name of the Hasidic master and grandson of the Besht Moshe Hayyim Ephraim of Sudilkov (17481800), it was customary among Hasidim to tell non-Jewish tales and to reveal their secret meaning to the audience. ${ }^{101}$ What is more, his younger contemporary and nephew Nahman of Bratslav (1771-1810) thought that "the primal act of breakage that scattered the sparks of holiness throughout the profane universe had affected even the tales that other people tell," and that the tiqqun "could only work if the tales themselves were redeemed from their profane outer shell." 102 This very practice was ridiculed in Maskilic satires, as a manuscript recently published by Shmuel Werses

97 The verse reads "of his belly" (בטנו).

${ }_{98}$ MS Jerusalem, National Library of Israel, Heb. 2134=8 (formerly (MS Wrocław Jewish Theological Seminary 220) 36a.

99 Jeremy Phillip Brown, "Distilling Depths from Darkness: Forgiveness and Repentance in Medieval Iberian Jewish Mysticism" (PhD diss.; New York University, 2015) 22. On the creative and maternal element of the female as "the transvaluation of the feminine into the masculine," see Elliot R. Wolfson, "On Becoming Female: Crossing the Gender Boundaries in Kabbalistic Ritual and Myth," in Gender and Judaism: The Transformation of Tradition (ed. T. M. Rudavsky; New York: New York University Press, 1995) 214-15.

${ }^{100}$ Wolfson, Luminal Darkness, 250-51, and idem, Circle in the Square, 98-106.

${ }^{101}$ See Reshit Hokhmah: An Unknown Anti-Hasidic Manuscript (ed. Shmuel Werses and Jonatan Meir; Jerusalem: The Mandel Institute of Jewish Studies, 2011) 37 n. 400 (Hebrew).

${ }^{102}$ David G. Roskies, “The Master of Prayer: Rabbi Nahman of Bratslav," in God's Voice from the Void: Old and New Studies in Bratslav Hasidism (ed. Shaul Magid; Albany: State University of New York Press, 2002) 67-102, at 73. 
and Jonatan Meir reveals. ${ }^{103}$ It includes a tale whose plot is somewhat similar to that of "The Wolf and the Seven Young Goats" recorded by the Brothers Grimm, in which a bear devours four sons who are hiding in their elderly mother's locked house while she is away. By the time the bear returns to her, she puts him to sleep, cuts his belly open, and releases her four children. The author continues to deride the Hasidim, who read the story as an allegory for the redemption of the divine portion held hostage by the qelippot, equating the bear with Samael, the mother with the Šekinah, and the children with the holy sparks. Most importantly, however, the children's release is depicted with an altered version of Job 20:15-the very same verse from which the divine name $H B^{\prime \prime} V$ is derived in the addenda for the rectification of the waste of seed.

\section{Popularization and Censorship: Strategies and Counterstrategies}

With the integration of the addendum into non-kabbalistic prayer books, its detachment from the initial Lurianic context reached its peak. Brief introductory remarks - such as "the kabbalists wrote that one must pray this formula for the waste of seed before ending [the tenth] blessing [of the Amidah]"- - remained the only remnants that pointed to the kabbalistic origin of this custom. ${ }^{104}$ The prayer's decontextualization from its former technical and metaphysical framework is thus also a prime example of what Jacob Elbaum has described as "the doctrine that there is religious significance also to the performance of actions whose theological basis is unknown" to the practitioner. ${ }^{105}$ In our case, this means that even if one does not understand the exact theosophical and theurgical workings of the supplication, or the correlation of the name $H B^{\prime \prime} V$ with the wording of the blessing, one is nevertheless urged to recite it. Put differently, the lack of special knowledge seems not to affect the efficiency of the practice.

At the same time, the very integration of kabbalistic materials into a nonkabbalistic context posed a problem for certain sectors of Jewish society. While the popularity of the different versions of the addenda was especially enduring in Eastern Europe, one can witness a change of attitude in German lands toward the end of the eighteenth century. Ismar Elbogen, in his comprehensive study of Jewish liturgy, writes that it was the merit of the exegete and grammarian Wolf Heidenheim (1757-1832), who has been called the "Mendelssohn of the prayer book," "to cleanse [it] from the distortions it had suffered from kabbalistic influence . . . by deleting the prayer addenda introduced by Lurianic mysticism." 106 The prayer

${ }^{103}$ Ibid., 36-37. Even though the story does not mention the actual nature of their sins (alluding to Ezek 8:18), it seems reasonable to assume, in the given context, that it hints at a sexual transgression.

${ }^{104}$ According to the wording of an unidentified prayer book, Genizah Reckendorf, MS R 1305, $24 \mathrm{~b}$.

${ }^{105}$ Jacob Elbaum, "Aspects of Hebrew Ethical Literature in Sixteenth-Century Poland," in Jewish Thought in the Sixteenth Century (ed. Bernard Dov Cooperman; Cambridge: Harvard University Press, 1983) 146-66, at 158.

${ }^{106}$ Ismar Elbogen, Der jüdische Gottesdienst in seiner geschichtlichen Entwicklung (Leipzig, 1913) 396 (my translation). The rendering of the English edition is clearly toned down when 
book Heidenheim edited was first published in Rödelheim in 1799 as Siddur Safah Berurah. Together with Selig Pinchas Bamberger's (1872-1936) German translation, it was republished as Siddur Sefat 'Emet, which is, to this day, one of the most popular prayer books among German-speaking Jews.

In the wake of inner-Jewish censorship, the occurrence of handwritten versions of the tiqqun qeri addenda was on the rise. Two types of this phenomenon can be witnessed in the materials preserved in Southern German genizot: either the censored passage was reintegrated in the margins of the page, or it was copied on a separate sheet that could be inserted into the non-kabbalistic prayer book. Jonatan Meir described the very same occurrence in a study of the popularization of Kabbalah in nineteenth-century Jerusalem. Yosef Ḥayyim of Baghdad, in his Tiqqun Tefillah, published anonymously in 1870, recommends appending handwritten tiqqunim in the margins of one's personal prayer books. ${ }^{107}$ In some instances, kabbalistic supplementary prayers were even printed on single sheets so that they could be attached to the "regular" prayer books. ${ }^{108}$ In the German context, it is likely that the addition of glosses or extra handwritten sheets testifies to a counterstrategy that was attempting to resist the "de-kabbalization" of daily life.

\section{Conclusion}

As has been shown, the impact of the Lurianic strategy of preserving and rectifying individuals from sexual impurity is highly remarkable. What began as a marginal note in an elaborate representation of the Lurianic myth of creation eventually turned into an "all-purpose" tool for guarding the covenant. With the exception of prayer books that follow the Lurianic rite, elaborate mystical intentions and unifications of divine names are almost nonexistent in the late adaptations of the addendum. The various alterations of the supplication therefore illustrate the shift from an elitist to a popular practice, as well as from a theosophical to a theurgical and magical realm.

In light of the previous examples, it becomes apparent that the Zoharic notion of spilling seed as a transgression that has no repentance, as well as the later adaptations that interpret wasting sperm as an act of murdering one's own offspring, had a lasting impact on the everyday practice of Jews living in the early modern era. ${ }^{109}$ The recital of variants of the supplication prior to bedtime, during the morning prayer, and, in some instances, even three times a day, ${ }^{110}$ clearly illustrates the ubiquity of

compared to the German original (idem, Jewish Liturgy: A Comprehensive History [Philadelphia: New York: Jewish Publication Society, 1993] 298).

${ }^{107}$ Jonatan Meir, "Toward the Popularization of Kabbalah: R. Yosef Hayyim of Baghdad and the Kabbalists of Jerusalem," Modern Judaism 33 (2013) 148-72, at 154.

${ }^{108}$ Ibid., 157.

${ }^{109}$ See, e.g., Pachter, "Shmirat Habrit," 216.

${ }^{110}$ Hayyim Yosef David Azulai, Siddur la-Hid"a' (Jerusalem: Ahavat Shalom, 2000). The addendum is included in the šaharit (169-170), minhah (259), and 'aravit (292-93) services of the weekday tiqqun qeri prayer. 
the concern with the problem at hand. Yet the inflationary recommendations of the prayer may also reflect the resentment of elitist circles toward the negligent attitude of their contemporaries. Hence, the Safedian kabbalist El'azar Azikri writes in Sefer Haredim that "there are (quite) a few men that err in regard to this particular transgression, as they do not know that it is prohibited." 111 Naftali Bakhrakh, in his 'Emeq ha-Melek, also refers to the large number of people who transgress "the holy covenant." 112 Moreover, since the addendum bears an atoning quality, it also functions as a sort of panacea effective for nullifying the individual and cosmic ramifications of the transgression. In Semah Șaddiq, it is stated that when performing the above-mentioned rectification of the waste of seed outlined in Hemdat Yamim, "one does not need to fast," since the healing power of study is regarded as "a remedy for the sin of qeri." 113 What is more, Vital himself acknowledges that by the sheer power of repentance, one is able to free the souls trapped in the realm of the husks and return them "to the treasure of holiness that is called 'body." "114

On a larger scale, the problem of sexual impurity goes much deeper. Shilo Pachter has already remarked that in Lurianic myth, God's autoerotic action in the process of creation is for the first time explicitly depicted as a failure, thus making the waste of semen, at least implicitly, the epitome of failure in human history. ${ }^{15}$ Viewed in this light, the perception of the male Jew being envisioned in the image of God also points to a shared sexual defectiveness. Overcoming this condition calls for the rectification of the momentous mishap of the divine by constraining the libido intrinsic to human creation. It requires the task of acting permanently against one's nature. Emerging from this paradoxical situation, the prayer addendum does not offer a real solution to the predicament but constitutes a means to mitigate the symptoms. Thus, the restorative quality of the prayer supplication differs factually from other types of tiqqunim, as it is conceptualized as a method of healing through destruction: if man is not capable of erasing his desires, he is at least encouraged to crush the qelippot in order to kill his unwanted demonic offspring. As the prayer's opening formula of "May it be Your will" (yehi rașon) suggests, it is ultimately not in the individual's power to execute the required actions, but only to attempt to elicit God's favor. If taken seriously, these circumstances place the individual in a situation in which he can either come to terms with the realization that he is doomed to fail and can only reduce the level of damage or condition himself to live a most stringent way of life that aims at breaking his most basic urges. Psychologically, the sense of guilt and the hardly bearable responsibility for the erroneous state of the

${ }^{111}$ El'azar Azikri, Sefer Haredim (Venice, 1601) 65a. See also Isaiah Horowitz, Šney Luhot ha-Brit (Amsterdam 1698) 100a.

${ }^{112}$ Bakhrakh, 'Emeq ha-Melek, 1:95.

${ }^{113}$ On the title page of Semah Saddiq (Livorno, 1784). Semah Saddiq is an abbreviated version of Hemdat Yamim (see Scholem, Lurianic Kabbalah, 326).

${ }^{114}$ Hayyim Vital, Ša ar ha-Pesuqim (Jerusalem: Ahavat Shalom, 2017) 192; Moshe Idel, "The Tsadik and His Soul's Sparks: From Kabbalah to Hasidism," JQR 103 (2013) 196-240, at 212-13.

${ }^{115}$ Pachter, "Shmirat Habrit," 203. 
cosmos triggered in both scenarios represent a major dilemma. This predicament has been poignantly captured in Chaim Grade's novel The Yeshiva, where the figure of Moshe Chayit Lohoyshker, a somewhat outcast yeshiva student of Novardok, reasons the attempted suicide of his ascetically inclined fellow-student Shimshl Kupishker by way of the following explanation:

Let's say that his enormous lust for a woman may have made him have a nocturnal emission. Or very possibly he masturbated. But afterwards, or perhaps even while doing it, he knew he was committing a terrible sin-he was spilling seed in vain. So he began to consider what kind of punishment he must administer to redeem himself from that sin. Fasting and rolling in the snow is nothing to him. To be eternally cut off from the people of Israel, as Er and Onan, the sons of Judah, were - that too means nothing to him. Even the fires of Gehenna aren't hot enough to burn out the sin he had committed. So that onanist plucked at his body with his dirty fingernails until he came up with the proper punishment and revenge on himself: he would deprive himself of his most precious possession. He would commit suicide and thereby lose the world to come, just as he refused to have this world of here and now. Saints renounce the world to come in order to earn a mitzvah, and he would renounce the world to come in order to punish himself for that transgression. ${ }^{116}$

The very same challenge continues to this day, and it is particularly pronounced in the rigorous demands of sexual purity in the Hasidic world, vividly recorded by the newly religious filmmaker Ori Grudler in his recently released film Sacred Sperm. ${ }^{117}$ Toward the end of the autobiographical documentary, which deals with Grudler's struggle with his "sinful" past and the challenges of educating his son in modesty (seni 'ut), the Bratslav rabbi Shmu'el Stern concisely summarizes the contemporary point of view, claiming that "guarding the covenant is the foundation of the world." 118

116 Chaim Grade, The Yeshiva, vol. 2, Masters and Disciples (Indianapolis: Bobbs-Merrill, 1977) 296-97.

117 Ori Gruder, Sacred Sperm (Santa Monica, CA: Menemsha Films, 2016; https://www. menemshafilms.com/sacred-sperm).

${ }^{118}$ Alluding to Prov 10:25, Stern utilizes a language that in and of itself is highly charged with phallic symbolism. 